\title{
Torrance Test of Creative Thinking: The question of its construct validity
}

\author{
Leandro S. Almeida ${ }^{a}$, Lola Prieto Prieto ${ }^{\mathrm{b}, *}$, Mercedes Ferrando $^{\mathrm{b}}$, Emma Oliveira $^{\mathrm{a}}$, \\ Carmen Ferrándiz ${ }^{\mathrm{b}}$ \\ a University Do Minho University Braga, Portugal \\ b University of Murcia, Spain
}

\section{A R T I C L E I N F O}

\section{Article history:}

Received 31 October 2007

Received in revised form 29 February 2008

Accepted 10 March 2008

Available online 15 March 2008

\section{Keywords:}

Creativity

Divergent thinking

Insight

Dimensions of creativity

\begin{abstract}
A B S T R A C T
Some cognitive dimensions are internationally considered by psychologists to describe and to assess creativity. For example, (Guilford, P. (1976). Creatividad y Educación. Buenos Aires. Ed. Paidos) and (Torrance, E. P. (1977). Discovery and nurturance of giftedness in the culturally different. Reston, VA: Council on Exceptional Children) suggested fluency, flexibility, originality and elaboration are the main cognitive processes used to define and assess creativity. However, data from several empirical studies did not confirm a factor structure in accordance with such cognitive functions, despite of the wide use of TTCT (Torrance Tests of Creative Thinking) in different countries. In this paper, we present new data collected in Spain and Portugal with TTCT. According to our data, those cognitive functions supposedly present on a subject's performance are not so strong as to explain the variance in scores. Elaboration factors assume some variance explanation, but the main factors are identified with the products in each subtest, suggesting the importance of format, content and demand on TTCT specific tasks. Consequently, we suggest some reflections to amplify the debate concerning the definition of creativity and its evaluation in psychology.
\end{abstract}

(c) 2008 Published by Elsevier Ltd.

\section{Introduction}

Creativity is a complex facet essential to understanding human development (Kerr \& Gagliardi, 2003). In 1950, J.P. Guilford in his discourse as president of the American Psychological Association proposed studying and measuring creativity as an intellectual human function (Piirto, 1998). Since then, different conceptions of creativity have emerged attempting to understand the psychological meaning of the construct. For example, the psychoanalysis perspective outlined that personality is the main characteristic of creativity; while Güestaltists, such as Wertheimer (1945) and Duncker (1945), emphasised the importance of problem perception, the reorganisation of elements involved in the problem and the insight processes as principal keys in creative behaviour.

Cognitive perspective offers a holistic vision of creativity, which includes non-cognitive factors (personal and social) in creative production. Furthermore, Amabile (1983) emphasises the role of the environment, the person, and intrinsic motivation, while Csikzentmihalyi (1988) includes the factor of chance in his systematic theory.

It is important to note that the perspective adopted will influence the understanding of creativity (Alencar \& Fleith, 2003; Morais, 2001; Wechsler, 2002).

\footnotetext{
* Corresponding author. Professor of Educational Psychology Murcia University (Spain) Campus Espinardo s/n 30100. Murcia (Spain), Tel.: +34 968 364072. E-mail address: lola@um.es (L.P. Prieto).
} 
Even when a consensus about what is creativity appears elusive there is no doubt that creativity seems to reflect certain personality or style factors. Therefore, it is possible to consider the importance of personality dimensions on creativity such as an open mind, novelty, tolerance to ambiguity, as well as some cognitive functions such as ideational fluency and thinking flexibility.

Considering the literature in this field (e.g. Csikzentmihalyi, 1988), pondering the bipolarity of some cognitive dimensions is a suitable option in advancing toward a construct definition of creativity. Almeida and Prieto (2007) present some topics in order reach a better definition of creativity as a cognitive characteristic. For example (1) is more associated with divergent than convergent thinking and production; (2) is more an individual attribute than an universal or normative construct; (3) is more related to insight and novelty than to learning and routine behaviour; (4) can be more characterized by problem-finding than by problem-solving; and (5) use more remote than spontaneous or frequent ideational association.

According to Alencar and Fleith (2003), "one of the main dimensions included in the majority definitions of creativity is the generation of a new product, idea, original invention, re-elaboration, improve products or ideas existents" (pp: 13-4). The idea of novelty and original products is included in the other authors' definitions of creativity as well. For example, Guilford (1967) emphasizes “divergent production”. Characteristics of this production include: fluidity, flexibility, originality and elaboration. These characteristics, or dimensions, were assumed by Torrance $(1969,1974)$ in his theory and in the evaluation he proposed (Torrance Thinking Creative Test - TTCT). Torrance (1969) defined creativity as the capacity to detect gaps, propose various solutions to solve problems, produce novel ideas, re-combine them, and intuit a novel relationship between ideas. In terms of dimensions, Guilford and Torrance have defined and consolidated different processes that have been universally assumed in the assessment of creativity: fluency (production of ideas), flexibility (production of different ideational categories), originality (production of unusual ideas), and elaboration (persistency on introducing details to products).

From the cognitive perspective, Davidson and Sternberg (1984) outlined insight skills as the key processes of creativity. Insight includes three principal processes: (a) selective encoding is the separation of relevant from irrelevant information; (b) selective comparison is the ability that to link new information with the previous knowledge; and (c) selective combination is the capacity to put disparate pieces of information together in a novel and useful way. In addition, Sternberg (2005) emphasized that the principal keys of creativity are novelty, unusualness, and non-familiarity. Creativity is defined as the skills and attitudes needed for generating ideas and products that are (a) relatively novel (original/unexpected); (b) high in quality; and (c) appropriate to the task at hand (useful).

Even though creativity seems to be composed of several factors that make its evaluation difficult and elusive, it is commonly accepted that the TTTC - which have been used internationally - is one of the best forms of creativity measurement.

The TTCT was developed in the early days of studying creativity, allowing the study of its construct validity using longitudinal studies (i.e. Cramond, Matthwes-Morgan, and Bandalos, 2005; Plucker, 1999; Torrance (1966b, 1980, 1981a); Torrance \& Wu, 1981; Yamada \& Tam, 1996). Nevertheless, studies regarding its internal and structure validity have led to different results (i.e. Chase, 1985, cfr., Hocevar \& Michael, 1979; Kim, 2006a,b; Treffinger, 1985). In addition, most of the studies have been carried out using only an American population.

\section{Our empirical works and contributions to Torrance research}

In this paper, we present the results of three empirical studies that were conducted in Spain and Portugal. The aim is to analyse the construct validity of TTCT. In accordance with Guilford and Torrance, we expect the cognitive dimensions of creativity (flexibility, fluency, originality, and elaboration) to be consistent and stable when assessing students' performance in the different TTCT tasks. The consistency and stability of scores are imperative in considering these cognitive functions as important dimensions of creativity and determinants of creative production.

\subsection{Instrument}

TTCT is the most well-known and widely used test of measuring creativity (Baer, 1993; Kim, 2006a; Ferrando, 2006; Wechsler, 2002). The test includes figural and verbal subtests. The TTCT-Verbal has two parallel forms, A and B, including the following subtests: (a) Asking Questions and Making Guesses (subtests 1, 2 and 3), where participants write out questions and make guesses about possible causes and consequences of situations based on a drawing of a scene; (b) Improvement of a Product (subtest 4), where the examinees list ways to change a toy elephant so that they will have more fun playing with it; (c) Unusual Uses (subtest 5), where the examinees list interesting and unusual uses of a cardboard box; and (d) Supposing (subtest 6), where the examinees are asked to list all the consequences should an improbable situation come true Torrance $(1969,1974)$.

The TTCT-Figural consists of two parallel forms with three subtests: (a) compose a drawing; (b) finish a drawing; and (c) compose a different drawing parting from parallel lines (Torrance, 1974).

Both forms are oriented to assess four principal cognitive processes of creativity: (a) fluency or number of relevant responses; (b) flexibility as referred to a variety of categories or shifts in responses; (c) originality entails considering novelty responses, not familiar and unusual, but relevant; and (d) elaboration as referred to the number of details used to extend a response. 
Table 1

Factorial analysis of scores on three figurative subtests

\begin{tabular}{|c|c|c|c|c|}
\hline \multirow[t]{2}{*}{ Subtests/dimensions } & \multicolumn{3}{|c|}{ Factors } & \multirow[t]{2}{*}{$h^{2}$} \\
\hline & I & II & III & \\
\hline Subtest 1-F: originality & & & .39 & .16 \\
\hline Subtest 1-F: elaboration & & & .73 & .55 \\
\hline Subtest 2-F: fluency & & .92 & & .89 \\
\hline Subtest 2-F: flexibility & & .90 & & .84 \\
\hline Subtest 2-F: originality & & .83 & & .71 \\
\hline Subtest 2-F: elaboration & & & .84 & .73 \\
\hline Subtest 3-F: fluency & .93 & & & .93 \\
\hline Subtest 3-F: flexibility & .93 & & & .93 \\
\hline Subtest 3-F: originality & .92 & & & .91 \\
\hline Subtest 3-F: elaboration & .39 & & .74 & .71 \\
\hline Eigen-values & 4.07 & 2.02 & 1.30 & \\
\hline \%Variance explained & 40.75 & 20.20 & 13.08 & \\
\hline
\end{tabular}

Table reproduced with permission from Ferrando et al. (2007).

\section{Study 1 (Ferrando, 2006)}

Participants: 649 children (5-12 years old) took part in this research. The students were from different schools of Murcia and Alicante (Spain).

Instrument: The Torrance Thinking Creative Test. In this particular study we applied the three subtests of the TTCTFigurative Form:

(a) compose a drawing; (b) finish a drawing; and (c) compose a different drawing parting from parallel lines.

This Form was adapted for the first time to be used within the Spanish cultural context by the "High Ability Research Team at Murcia University." Main changes concern the scoring rubrics for the Originality dimension (for more details consult, López, 2001).

Procedure: These data were collected from different schools using a regular class session given that the TTCT-Figurative Form is suitable for group administration.

Data analysis: A factor analysis of principal components, with varimax rotation, was applied. The results are presented in Table 1.

The factorial analysis showed that the main factors are not identified with the cognitive processes assumed in literature to define creativity, but more related to the specificity of demands in each task (subtest). If factor III can be associated with "elaboration process", Factors I and II are related to subtest 3 and subtest 2, respectively. These data suggested that the content, format and/or demands of each task are more decisive for a student's performance than the cognitive processes used to define and assess creativity. Originality, fluency, and flexibility are not so strong in the performance explanation, which suggests some difficulties in identifying creativity by these processes. If those cognitive functions are good indicators of creativity, we can assume that these tasks are not good stimuli for creativity performance assessment.

\section{Study 2 (Oliveira, 2007)}

Participants: 595 pre-adolescents took part in this study (from 10 to 14 years old; 5 th and 6 th grades). This sample included 100 students who had been accelerated during elementary school (by early entrance or skipping 1 year). By Portuguese legislation, this educative measure is applied when children show a significant precocity in learning and cognitive development. The students belonged to different schools in northern Portugal (Porto, Viana and Braga).

Instruments: Six subtests of TTCT (three verbal and three figurative) were applied in this study.

TTCT-Verbal-Form: "Asking Questions and Making Guesses" (subtests 1, 2 and 3).

TTCT-Figurative Form: (a) compose a drawing; (b) finish a drawing; and (c) compose different drawing parting from parallel lines.

Procedures: The TTCT subtests were applied in class after explaining our research objectives and assuring the students that participation was voluntary. The instructions were translated to Portuguese language from the original manual of the tests (Torrance, 1976) and the quotation of scores, were validated in a previous study.

Data analysis: We conducted a factor analysis using the principal components model, with varimax rotation. The results are presented in Table 2 .

The factorial analysis showed, again, that the main factors are not identified as cognitive processes, only with the specificity of tasks. The initial five factors are identified with specific TTCT tasks or subtests, which are independent of the cognitive processes (fluency, flexibility and originality). Only the sixth factor seems to have an identification related to a cognitive process (elaboration), which means there is insufficient consistency to support the premise of defining creativity by cognitive dimensions. 
Table 2

Factor analysis on TTCT subtests/dimensions

\begin{tabular}{|c|c|c|c|c|c|c|c|}
\hline \multirow[t]{2}{*}{ Subtests/dimensions } & \multicolumn{6}{|l|}{ Factors } & \multirow[t]{2}{*}{$H^{2}$} \\
\hline & I & II & III & IV & V & VI & \\
\hline Subtest 3-F: Fluency & .92 & & & & & & .91 \\
\hline Subtest 3-F: Flexibility & .89 & & & & & & .67 \\
\hline Subtest 3-F: Originality & .86 & & & & & & .80 \\
\hline Subtest 2-V: Fluency & & .90 & & & & & .93 \\
\hline Subtest 2-V: Originality & & .88 & & & & & .77 \\
\hline Subtest 2-V: Flexibility & & .81 & & & & & .86 \\
\hline Subtest 3-V: Fluency & & & .90 & & & & .94 \\
\hline Subtest 3-V: Originality & & & .87 & & & & .79 \\
\hline Subtest 3-V: Flexibility & & & .82 & & & & .85 \\
\hline Subtest 1-V: Fluency & & & & .90 & & & .09 \\
\hline Subtest 1-V: Originality & & & & .83 & & & .56 \\
\hline Subtest 1-V: Flexibility & & & & .79 & & & .87 \\
\hline Subtest 2-F: Fluency & & & & & .89 & & .82 \\
\hline Subtest 2-F: Flexibility & & & & & .88 & & .59 \\
\hline Subtest 2-F: Originality & & & & & .75 & & .78 \\
\hline Subtest 2-F: Elaboration & & & & & & .86 & .93 \\
\hline Subtest 1-F: Elaboration & & & & & & .73 & .85 \\
\hline Subtest 3-F: Elaboration & & & & & & .72 & .84 \\
\hline Subtest 1-F: Originality & .349 & & & & & & .70 \\
\hline Eigen-value & 6.01 & 2.69 & 1.88 & 1.47 & 1.34 & 1.24 & \\
\hline \%Variance explained & 31.61 & 14.17 & 9.90 & 7.73 & 7.05 & 6.54 & \\
\hline
\end{tabular}

Table reproduced with permission from Oliveira (2007).

\section{Study 3 (Antunes \& Almeida (2007)}

Participants: 310 pre-adolescents took part in this research (from 10 to 15 years old; 5th and 6th grades); they belonged to different schools of the Braga Region (Portugal).

Instrument: In this study, we applied two subtests of TTCT-Verbal Form: subtest 4 (improve a product), and subtest 5 (Unusual Uses); and two subtests of TTCT-Figurative-Form: subtest 2 (finish a drawing) and subtest 3 (parallel lines).

Procedures: As in the previous study, we applied the TTCT subtests in class after explaining our research objectives and assuring the students of voluntary participation.

Data analysis: A factor analysis of principal components, with varimax rotation, was applied (Table 3).

The factor analysis again presents the inconsistency of fluency, flexibility and originality as the main determinants or dimensions of creative production, namely if we consider these tasks or subtests of TTCT as stimuli for creativity assessment. If elaboration assumes some stability along the four subtests used (5th factor), the other four factors identified concern the specificity of each task of the TTCT that we applied.

Table 3

Factor analysis on TTCT subtests/dimensions

\begin{tabular}{|c|c|c|c|c|c|c|}
\hline \multirow[t]{2}{*}{ Subtests/dimensions } & \multicolumn{5}{|c|}{ Factors } & \multirow[t]{2}{*}{$H^{2}$} \\
\hline & I & II & III & IV & V & \\
\hline Subtest 4-V: fluency & & & & .81 & & .78 \\
\hline Subtest 4-V: flexibility & & & & .77 & & .63 \\
\hline Subtest 4-V: originality & & & & .40 & & .37 \\
\hline Subtest 4-V: elaboration & & & & .69 & & .50 \\
\hline Subtest 5-V: fluency & & .90 & & & & .87 \\
\hline Subtest 5-V: flexibility & & .91 & & & & .87 \\
\hline Subtest $5-\mathrm{V}$ : originality & & .83 & & & & .73 \\
\hline Subtest 5-V: elaboration & & & & & .67 & .48 \\
\hline Subtest 2-F: fluency & & & .82 & & & .87 \\
\hline Subtest 2-F: flexibility & & & .87 & & & .89 \\
\hline Subtest 2-F: originality & & & .57 & & & .43 \\
\hline Subtest 2-F: elaboration & & & & & .72 & .65 \\
\hline Subtest 3-F: fluency & .84 & & & & & .84 \\
\hline Subtest 3-F: flexibility & .87 & & & & & .83 \\
\hline Subtest 3-F: originality & .75 & & & & & .61 \\
\hline Subtest 3-F: elaboration & .53 & & & & .60 & .67 \\
\hline Eigen-value & 4.85 & 2.05 & 1.60 & 1.33 & 1.20 & - \\
\hline \%Variance explained & 30.28 & 12.79 & 9.99 & 8.30 & 7.47 & - \\
\hline
\end{tabular}

Table reproduced with permission from Antunes and Almeida (2007). 


\section{Discussion and conclusion}

The current study aimed to examine the construct validity of the TTCT scores by analyzing three recent studies in Spain and Portugal. Data obtained with factor analysis in these three studies (Antunes \& Almeida, 2007; Ferrando, 2006; Oliveira, 2007), showed inconsistency of the cognitive processes (fluency, flexibility, originality and elaboration) as the main cognitive factors to define and assess creativity. The factors identified in our studies are not related to these cognitive functions, as well as do not comprise tasks of same content (verbal or figural). In these three studies, the factors are related to each task test in an independent way. This seems to translate the importance of each task's demands, requirements and format on subjects performance.

Although some cognitive processes (fluency, flexibility and originality) tend to be present in creativity definition and evaluation, our data don't illustrate such importance to explain the variance on the scores of the TTCT subtests. Our data showed that the elaboration process can be identified in the several tasks administrated. Even elaboration process is understand as the least important dimension of creativity (Clapham, 1998; Ferrando et al., 2007; Sternberg, 1999), it was the more consistent and stable dimension to explain the data in our three studies.

Taking the data into account, some questions must be considered in future research. For example, it is possible that our present data are associated to students' age. Perhaps the consistency and stability of the usual cognitive functions for creativity evaluation (fluency, flexibility, originality and elaboration) can be expected in older subjects. The Torrance Tests of Creative Thinking, the most widely used tests of creativity and the most referenced of all creativity tests, could be more appropriate for adults than for children and adolescents. Furthermore, some variations in the development of creative thinking along age have been described in the literature (Simonton, 1984), which may influence the results if different periods of development are being studied. In addition, further statistical analysis may be addressed with this data such as confirmatory factorial analysis, which may provide a different factor solution and therefore new data to TTCT construct validity.

Another question that requires more research concerns the importance of basic cognitive processes, tasks content and specific demands of task on creativity assessment. All those variables contribute to scores differentiation. Perhaps new and more neutral tasks should be designed to assess creativity in order to assure the presence of cognitive functions (fluency, flexibility, originality and elaboration) as main determinant of performance.

\section{Acknowledgements}

The development of the first research has been possible thanks to the funding of Spanish Ministry of Education through the project (SEJ2006-00520/EDUC) and by Séneca Foundation (Regional Agency of Science and Technology. Ref.: 03019/PHCS/05, Murcia, Spain).

\section{References}

Alencar, E. S., \& Fleith, D. S. (2003). Criatividade: Múltiplas perspectivas. Brasília: Editora Universidade de Brasília.

Almeida L., Prieto L., (2007). Creativity: The question of its construct validity. Paper presented to the BERA Annual Conference, held in London 5th - 8th September 2007.

Amabile, T. M. (1983). The social psychology of creativity: a componential conceptualization. Journal of Personality and Psychology, 45, $357-376$.

Antunes, A. P., \& Almeida, L. (2007). Avaliar a criatividad: Contibutos para validade de alguns subtestes do TPCT (Torrance Pensamento Creativity Test). Revista Psicologia e Educaçao, 6(1), 37-53.

Baer, J. (1993). Creativity and divergent thinking: A task-specific approach. Hillsdale: Lawrence Erlbaum.

Chase, C. I. (1985). Review of the Torrance Test of Creative Thinking. In J. V. Mitchell Jr. (Ed.), The ninth mental measurements yearbook (pp. 1631-1632). Lincoln: Buros Institute of Mental Measurement, University of Nebraska.

Clapham, M. M. (1998). Structure of figural forms A and B of the Torrance Tests of Creative Thinking. Educational and Psychological Measurement, 58, 275-283.

Cramond, B., Matthwes-Morgan, J., \& Bandalos, D. (2005). A report on the 40-year follow-up of TTCT: Alive and well in the millennium. Gifted Child Quartely, 49, 283-291.

Csikzentmihalyi, M. (1988). Society, culture and person: A system view of creativity. In R. Sternberg (Ed.), The nature of creativity. Cambridge, NY: Cambridge University Press.

Davidson, J. E., \& Sternberg, R. J. (1984). The role of insight in intellectual giftedness. Gifted Child Quarterly, 28, 58-64

Duncker, K. (1945). On problem solving. Psychological Monographs 58 (No. 270).

Ferrando, M. (2006). Creatividad e Inteligencia Emocional: Un Estudio Empírico en Alumnos Con Altas Habilidades. Tesos Doctoral. Murcia: Publicada en la Universidad de Murcia.

Ferrando, M., Ferrándiz, C., Bermejo, M. R., Sánchez, C., Parra, J., \& Prieto, M. D. (2007). Estructura interna y baremación del Test de Pensamiento Creativo de Torrance. Psicothema, 19(3), 489-496.

Guilford, J. P. (1950). Creativity. American Psychologist, 5, 444-454.

Guilford, J. P. (1967). The nature of human intelligence. New York: Mc-Graw-Hill.

Hocevar, D., \& Michael, W. B. (1979). The effects of scoring formulas on the discriminate validity of tests of divergent thinking. Educational and Psychological Measurement, 39, 917-921.

Kerr, B., \& Gagliardi, C. (2003). Measuring creativity in research and practice. In S. J. Lopez \& C. R. Snyder (Eds.), Positive psychological assessmente: A handbook of models and measures.. Washington, DC: American Psychological Association.

Kim, K. H. (2006a). Can we trust creativity tests? A review of the Torrance Tests of Creative Thinking (TTCT). Creativity Research Journal, $18(1)$, 3-14.

Kim, K. H. (2006b). Is creativity unidimensional or multidimensional? Analyses of the Torrance Tests of Creative Thinking Structure of Figural Forms A and B of the Torrance Tests of Creative Thinking. Educational and Psychological Measurement, 58, 275-283.

López, O. (2001). Evaluación y desarrollo de la creatividad. Murcia: Servicio de publicaciones Universidad de Murcia.

Morais, M. F. (2001). Definição e avaliação da criatividade: Uma abordagem cognitiva. Braga: CEEP-UM.

Oliveira, E.P.L. (2007). Alunos sobredotados: A aceleração escolar como resposta educativa. Tese de doutoramento. Braga, Universidade do Minho (Portugal).

Piirto, J. (1998). Understanding those who create. Scottsdale, AZ: Gifted Psychology Press.

Plucker, J. A. (1999). Is the proof in the pudding? Reanalyses of Torrance's (1958 to Present) longitudinal data. Creativity Research Journal, 1(2), 103-114. 
Simonton, D. K. (1984). Genius, creativity and leadership: Historiometric inquiries. Cambridge: Harvard University Press.

Sternberg, R. (1999). Handbook of creativity. New York: Cambridge University Press.

Sternberg, R. (2005). Creativity or creativities. International Journal of Human-Computer Studies, 63(4-5), 370-382.

Torrance, E. P. (1969). Creativity. What research says to the teacher. Washington, DC: National Education Association.

Torrance, E. P. (1966). The Torrance Tests of Creative Thinking - Norms-Technical Manual Research Edition - Verbal Tests, Forms A and B - Figural Tests, Forms A and B. Princeton NJ: Personnel Press.

Torrance, E. P. (1974). Norms technical manual: Torrance Tests of Creative Thinking. Lexington, Mass: Ginn and Co.

Torrance, P. (1976). Tests de pensée créative de E. P. Torrance: Manuel. Paris: Les Éditions du Centre de Psychologie Appliquée.

Torrance, E. P. (1980). Lessons about giftedness and creativity from a nation of 115 million overachievers. Gifted Child Quarterly, 24(1), 10-14.

Torrance, E. P. (1981). Empirical validation of criterion-referenced indicators of creative ability through a longitudinal study. Creative Child and Adult Quarterly, $6,136-140$

Torrance, E. P., \& Wu, T. (1981). A comparative longitudinal study of the adult creative achievements of elementary school children identified as highly intelligent and as highly creative. Creative Child and Adult Quarterly, 6, 71-76.

Treffinger, D. J. (1985). Review of the Torrance Tests of Creative Thinking. In J. V. Mitchell Jr. (Ed.), The ninth mental measurements yearbook (pp. 1632-1634). Lincoln: Buros Institute of Mental Measurements, University of Nebraska.

Wechsler, S.M. (2002). Avaliação da criatividade por figuras e palavras. Testes de Torrance: Versão brasileira. Campinas/SP: Laboratório de Avaliação Psicológica, PUC-Campinas.

Wertheimer, M. (1945). Productive thinking. New York: Harper.

Yamada, H., \& Tam, A. Y. (1996). Prediction study of adult creative achievement: Torrance's longitudinal study of creativity revisited. Journal of Creative Behavior, 30, 144-149. 